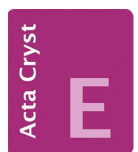

CRYSTALLOGRAPHIC COMMUNICATIONS

ISSN 2056-9890

Received 27 September 2021

Accepted 20 October 2021

Edited by M. Weil, Vienna University of Technology, Austria

Keywords: crystal structure; binuclear copper complex; DFT calculations; dimethylformamide; FT-IR spectroscopy; 3-nitrobenzoate.

CCDC reference: 2036680

Supporting information: this article has supporting information at journals.iucr.org/e

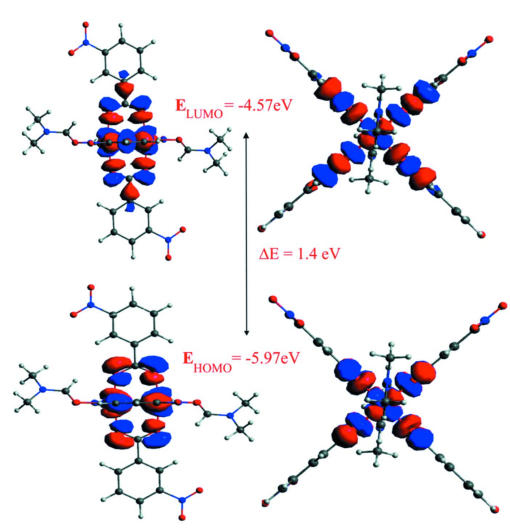

OPEN $\partial$ ACCESS

\section{Crystal structure, Hirshfeld surface analysis and DFT studies of tetrakis( $\mu$-3-nitrobenzoato- $\left.\kappa^{2} O^{1}: O^{1}\right)$ bis $[(N, N$-dimethylformamide- $\kappa O)$ - copper(II)] dimethylformamide disolvate}

\author{
Mavlonbek A. Ziyaev, ${ }^{*}$ Jamshid M. Ashurov, Alisher G. Eshimbetov and \\ Bakhtiyar T. Ibragimov
}

Institute of Bioorganic Chemistry, Uzbekistan Academy of Sciences, 100125, Mirzo Ulugbek Str.,83, Tashkent, Uzbekistan. *Correspondence e-mail: mavlonbek.z@mail.ru

The title compound, $\left[\mathrm{Cu}_{2}\left(\mathrm{C}_{7} \mathrm{H}_{4} \mathrm{NO}_{4}\right)_{4}\left(\mathrm{C}_{3} \mathrm{H}_{7} \mathrm{NO}\right)_{2}\right] \cdot\left(\mathrm{C}_{3} \mathrm{H}_{7} \mathrm{NO}\right)_{2}$, is a binuclear copper(II) complex located on an inversion center midway between the two copper(II) cations. The asymmetric unit consists of one $\mathrm{Cu}^{\mathrm{II}}$ cation, two 3-nitrobenzoato ligands, and two dimethylformamide (DMF) molecules, one of which coordinates to the $\mathrm{Cu}^{\mathrm{II}}$ cation and one is a solvate molecule. The carboxylate groups of the ligands bridge two $\mathrm{Cu}^{\mathrm{II}}$ cations with a $\mathrm{Cu}-\mathrm{Cu}$ distance of 2.6554 (6) $\AA$, completing a distorted octahedral $\mathrm{O}_{5} \mathrm{Cu}$ coordination environment. The dihedral angles between the carboxylate and the aromatic ring planes of the two independent ligands are different from one another, viz. 5.2 (3) and $23.9(3)^{\circ}$. The three-dimensional structure is consolidated by weak $\mathrm{C}-\mathrm{H} \cdots \mathrm{O}$ interactions and stabilized by $\pi-\pi$ stacking interactions between the aromatic rings. The complex and the free ligand were further characterized by Fourier-transform infrared spectroscopy (FT-IR), and the energies of the frontier molecular orbitals of the complex were determined by DFT calculations at the B3LYP/def2-TZVP level of theory.

\section{Chemical context}

Copper complexes have been explored extensively due to the fact that copper is a bio-essential element responsible for numerous bioactivities in living organisms (Tapiero \& Tew, 2003). Moreover, it is well known that $\mathrm{Cu}^{\mathrm{II}}$ complexation plays an important role in the pharmacological profile of antimicrobial activities (Haiduc \& Silvestru, 1989; Linder \& Goode, 1991). The first syn-syn bridged binuclear structure of a large number of copper(II) carboxylates with general formula $\left[\mathrm{Cu}(R \mathrm{COO})_{2}(L)\right]_{2}(L=$ co-ligand $)$, was reported for simple copper(II) acetate monohydrate (Van Niekerk \& Schoening, 1953). This classical structure consists of a binuclear $\left[\mathrm{Cu}_{2} \mathrm{O}_{8}\right]$ unit in which each copper(II) atom is surrounded by four oxygen atoms of carboxylate groups in an almost square-planar coordination. An additional ligand, here the $\mathrm{O}$ atom of a water molecule, is attached in an apical position at longer $\mathrm{Cu}-\mathrm{O}$ distances. The $\mathrm{Cu}-\mathrm{Cu}$ contact completes a distorted octahedral coordination sphere around each copper(II) atom. This motif is also observed in polymeric copper(II) carboxylates, where the apical ligand has two coordination centers and links dimeric units (Rao et al., 1983; Zhu et al., 2003). In the situation where the apical ligand is absent, a zigzag polymeric structure is formed with direct 
bonding between $\left[\mathrm{Cu}_{2} \mathrm{O}_{8}\right]$ units via the metal and one of the basal oxygen atoms of the neighbouring unit (Drożdżewski et al., 2004).

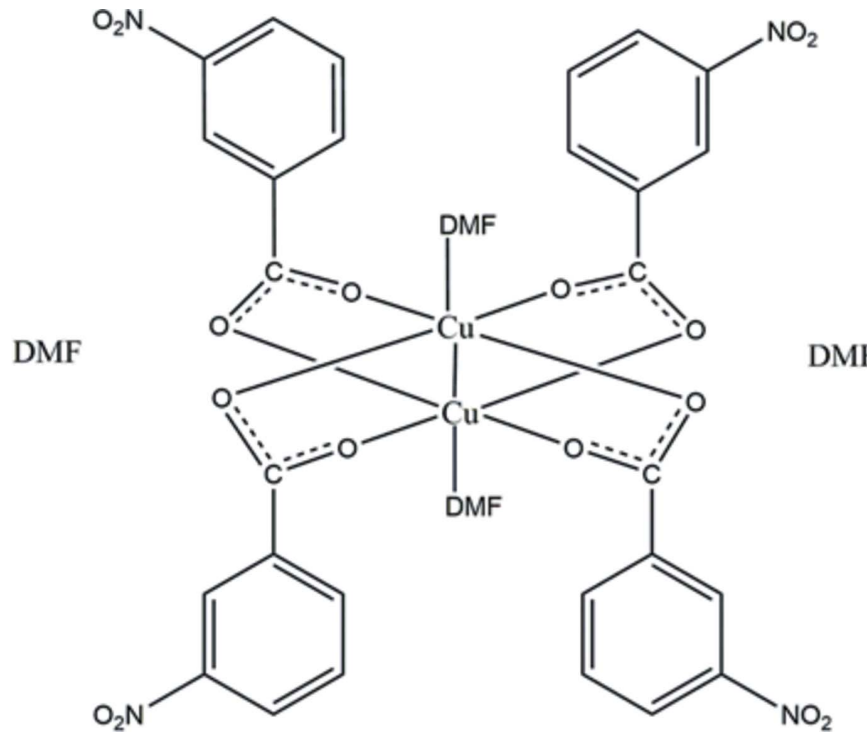

Copper(II) carboxylates, including copper(II) benzoates have been studied extensively from different points of view, because the carboxylato ligands exhibit different binding modes that are related to their properties, e.g. the basicity of the anion or the position of substituents on the aromatic ring. A bulky benzene ring substituent in an ortho position to the carboxylate group is believed to prefer the dimeric copper(II) benzoate structure (Harrison et al., 1972; Ueyama et al., 1996). In general, copper(II) carboxylates exhibit a dimeric paddlewheel cage structure. More than 500 crystal structures containing the $\mathrm{Cu}_{2}(\mathrm{OOCR})_{4}$ core have been determined on

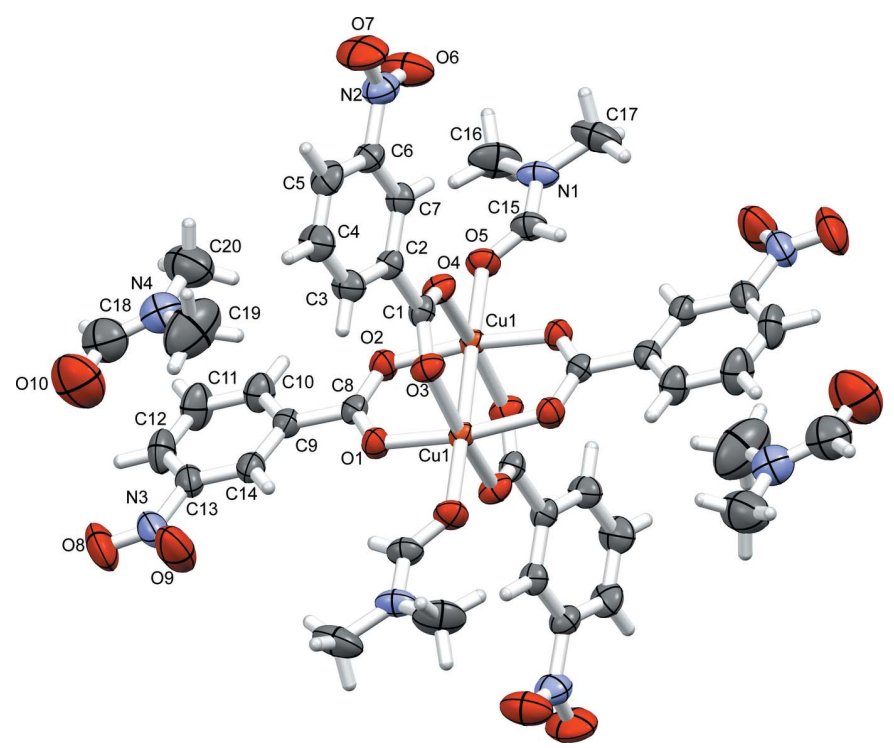

Figure 1

Molecular structure of $\left[\mathrm{Cu}_{2}\left(\mathrm{C}_{7} \mathrm{H}_{4} \mathrm{NO}_{4}\right)_{4}\left(\mathrm{C}_{3} \mathrm{H}_{7} \mathrm{NO}\right)_{2}\right] \cdot\left(\mathrm{C}_{3} \mathrm{H}_{7} \mathrm{NO}\right)_{2}$, with displacement ellipsoids drawn at the $30 \%$ probability level and $\mathrm{H}$ atoms shown as spheres of arbitrary radius. [Symmetry code: (i) $-x+1,-y+1$, $-z+1]$
Table 1

Selected bond lengths $(\AA)$.

\begin{tabular}{llll}
\hline $\mathrm{Cu} 1-\mathrm{O} 1$ & $1.9620(17)$ & $\mathrm{Cu} 1-\mathrm{O} 4^{\mathrm{i}}$ & $1.9751(16)$ \\
$\mathrm{Cu} 1-\mathrm{O} 3$ & $1.9650(16)$ & $\mathrm{Cu} 1-\mathrm{O} 5$ & $2.1453(17)$ \\
$\mathrm{Cu} 1-\mathrm{O} 2^{\mathrm{i}}$ & $1.9719(18)$ & $\mathrm{Cu} 1-\mathrm{Cu} 1^{\mathrm{i}}$ & $2.6554(6)$ \\
\hline
\end{tabular}

Symmetry code: (i) $-x+1,-y+1,-z+1$.

the basis of X-ray data and can be found in the Cambridge Structural Database (Groom et al., 2016), of which more than 250 are of the type $\left[\mathrm{Cu}_{2}(\mathrm{OOCR})_{4}(L)_{2}\right]$, where $L$ is an apical ligand with an oxygen, a nitrogen, a chlorine or a phosphorus donor atom. We report here on the molecular and crystal structure of a similar binuclear copper(II) complex, $\left[\mathrm{Cu}_{2}\left(\mathrm{C}_{7} \mathrm{H}_{4} \mathrm{NO}_{4}\right)_{4}\left(\mathrm{C}_{3} \mathrm{H}_{7} \mathrm{NO}\right)_{2}\right] \cdot\left(\mathrm{C}_{3} \mathrm{H}_{7} \mathrm{NO}\right)_{2}$, further characterized by infrared spectroscopy and DFT calculations.

\section{Structural commentary}

$\left[\mathrm{Cu}_{2}\left(\mathrm{C}_{7} \mathrm{H}_{4} \mathrm{NO}_{4}\right)_{4}\left(\mathrm{C}_{3} \mathrm{H}_{7} \mathrm{NO}\right)_{2}\right] \cdot\left(\mathrm{C}_{3} \mathrm{H}_{7} \mathrm{NO}\right)_{2}$ crystallizes as a dimethylformamide disolvate (Fig. 1). The neutral $\left[\mathrm{Cu}_{2}\left(\mathrm{C}_{7} \mathrm{H}_{4}\right.\right.$ $\left.\mathrm{NO}_{4}\right)_{4}\left(\mathrm{C}_{3} \mathrm{H}_{7} \mathrm{NO}\right)_{2}$ ] complex is centrosymmetric, with the inversion center located midway between the two $\mathrm{Cu}^{\mathrm{II}}$ cations. The asymmetric unit comprises one $\mathrm{Cu}^{\mathrm{II}}$ cation, two 3-nitrobenzoato ligands and two dimethylformamide molecules, one ligating and one as a solvent. The complex displays a paddle-wheel-shaped binuclear structure. Each $\mathrm{Cu}^{\mathrm{II}}$ cation is coordinated by four carboxylate oxygen atoms, forming the base of a slightly distorted square pyramid supplemented by a fifth oxygen atom of the dimethylformamide molecule at the apical position (Fig. 1). The overall distorted octahedral coordination environment is completed by the neighbouring $\mathrm{Cu}^{\mathrm{II}}$ cation with a $\mathrm{Cu}-\mathrm{Cu}$ distance of 2.6554 (6) $\AA$. This distance is close to that reported for similar binuclear complexes (Wang et al., 2018).

In the binuclear complex, the carboxylate groups of the 3-nitrobenzoato ligands link the two $\mathrm{Cu}^{\mathrm{II}}$ cations with short $\mathrm{Cu}-\mathrm{O}$ distances [from 1.9620 (17) to 1.9751 (16) Å; Table 1] whereas the distance to the $\mathrm{O}$ atom of the dimethylformamide ligand is elongated [2.1453 (17) $\AA$ ] . The carboxylate groups of the 3-nitrobenzoato ligands adopt a bidentate syn-syn bridging mode (Su et al., 2015; Wang et al., 2018), with dihedral angles between the carboxylate planes and the aromatic rings of $5.2(3)$ and $23.9(3)^{\circ}$, respectively.

\section{Supramolecular features}

The binuclear complex molecules are allocated with their central parts parallel to (200). The crystal packing shows slipped $\pi-\pi$ stacking interactions between the aromatic rings of symmetry-related 3-nitrobenzoato ligands $[C g 1 \cdots C g 1(-x+2,-y+1,-z+1)=4.117$ (2) A where $C g 1$ is the centroid of the C9-C14 phenyl ring; slippage $2.202 \AA]$. The nitro group of the second 3-nitrobenzoato ligand weakly interacts by $\mathrm{O} \cdots \mathrm{C}$ contacts $\left[\mathrm{O} 7 \cdots \mathrm{C} 17\left(-x+1, y+\frac{1}{2},-z+\frac{3}{2}\right)=\right.$ 3.087 (3) $\AA$ ] with the coordinating dimethylformamide molecule, forming zigzag chains parallel to [01]̄]. Through these interactions, the complex molecules form a channel-like 
Table 2

Hydrogen-bond geometry $\left(\AA,^{\circ}\right)$.

\begin{tabular}{lllll}
\hline$D-\mathrm{H} \cdots A$ & $D-\mathrm{H}$ & $\mathrm{H} \cdots A$ & $D \cdots A$ & $D-\mathrm{H} \cdots A$ \\
\hline $\mathrm{C} 4-\mathrm{H} 4 \cdots \mathrm{O} 4{ }^{\mathrm{ii}}$ & 0.93 & 2.47 & $3.360(4)$ & 161 \\
$\mathrm{C} 15-\mathrm{H} 15 \cdots \mathrm{O} 1$ & 0.93 & 2.50 & $3.100(4)$ & 123 \\
$\mathrm{C} 16-\mathrm{H} 16 C \cdots \mathrm{O} 5$ & 0.96 & 2.40 & $2.770(4)$ & 102 \\
$\mathrm{C} 19-\mathrm{H} 19 A \cdots \mathrm{O} 10$ & 0.96 & 2.35 & $2.753(8)$ & 104 \\
$\mathrm{C} 20-\mathrm{H} 20 C \cdots \mathrm{O} 10^{\mathrm{iii}}$ & 0.96 & 2.59 & $3.503(7)$ & 160 \\
\hline
\end{tabular}

Symmetry codes: (ii) $-x+1, y-\frac{1}{2},-z+\frac{3}{2}$; (iii) $-x+2, y+\frac{1}{2},-z+\frac{3}{2}$.

structure with the channels, in which the dimethylformamide solvate molecules are located, extending parallel to [010]. They interact via weak amide- $\pi$ interactions [N4 $\cdots C g 1=$ 3.597 (3) $\AA$ ] and weak $\mathrm{C}-\mathrm{H} \cdots \mathrm{O}$ (nitro group) hydrogen bonds (Fig. 2, Table 2). The latter interactions cause a greater rotation $\left[23.9(3)^{\circ}\right]$ of the aromatic ring relative to the carboxylate group in the second 3-nitrobenzoato ligand.

\section{Hirshfeld surface analysis}

Intramolecular and intermolecular interactions of $\left[\mathrm{Cu}_{2}\left(\mathrm{C}_{7} \mathrm{H}_{4} \mathrm{NO}_{4}\right)_{4}\left(\mathrm{C}_{3} \mathrm{H}_{7} \mathrm{NO}\right)_{2}\right] \cdot\left(\mathrm{C}_{3} \mathrm{H}_{7} \mathrm{NO}\right)_{2}$ were quantified by Hirshfeld surface analysis using Crystal Explorer 17.5 (Turner et al., 2017). The presence of strong interactions on the Hirshfeld surface is indicated by red spots, while the blue areas indicate weak interactions, as shown in Fig. 3. Two-dimensional fingerprint plots with all interactions and delineated into individual interactions together with their relative contributions are displayed in Fig. 4. The most important intermolecular interactions are $\mathrm{O} \cdots \mathrm{H} / \mathrm{H} \cdots \mathrm{O}(38.9 \%)$, followed by $\mathrm{H} \cdots \mathrm{H}(33.3 \%), \mathrm{C} \cdot \mathrm{H} / \mathrm{H} \cdots \mathrm{C}(12.7 \%)$ and $\mathrm{O} \cdots \mathrm{C} / \mathrm{C} \cdots \mathrm{O}(5.9 \%)$. Other interactions contribute less than $5 \%$ to the overall Hirshfeld surface.

\section{DFT calculations}

Theoretical calculations were carried out by the hybrid density functional theory (DFT) at the B3LYP level of theory (Becke, 1988; Lee et al., 1988) using Aldrich's def2-TZVP basis set, which has been successfully tested in one of our previous

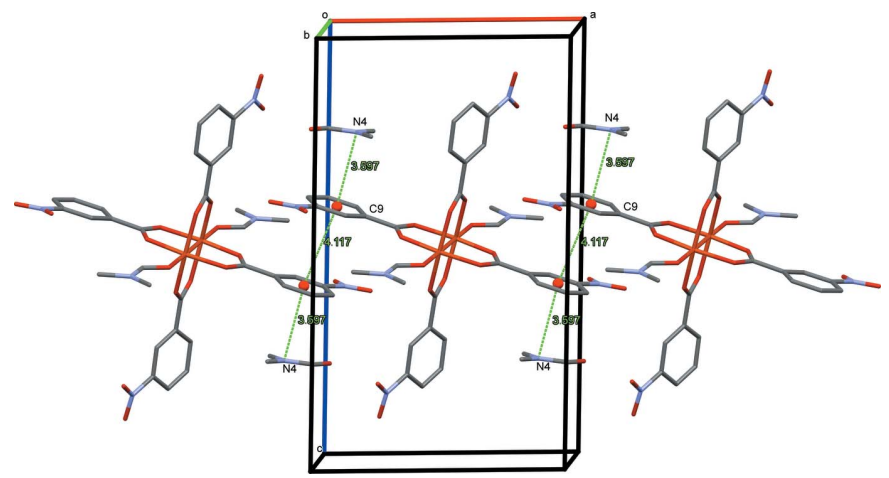

Figure 2

Non-aromatic-aromatic-aromatic interactions between adjacent binuclear metal units.

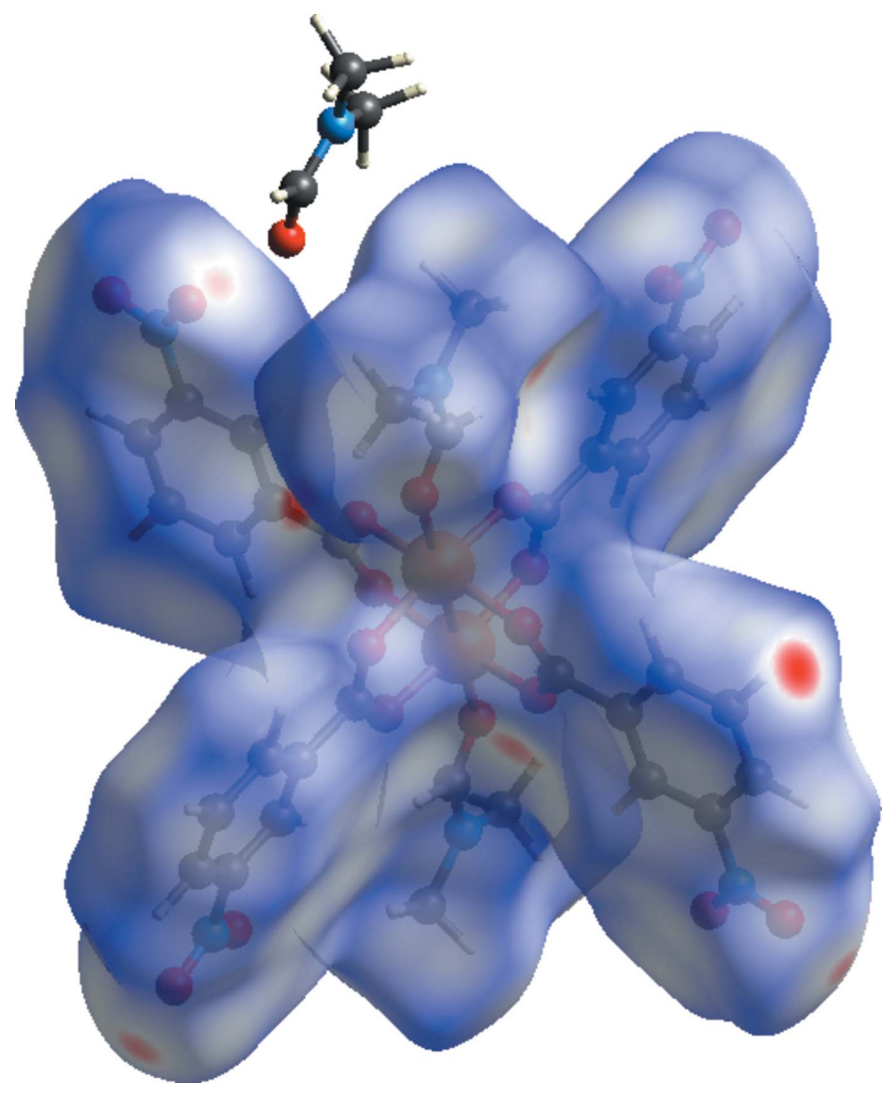

Figure 3

Three-dimensional Hirshfeld surface of the title compound mapped over $d_{\text {norm }}$.
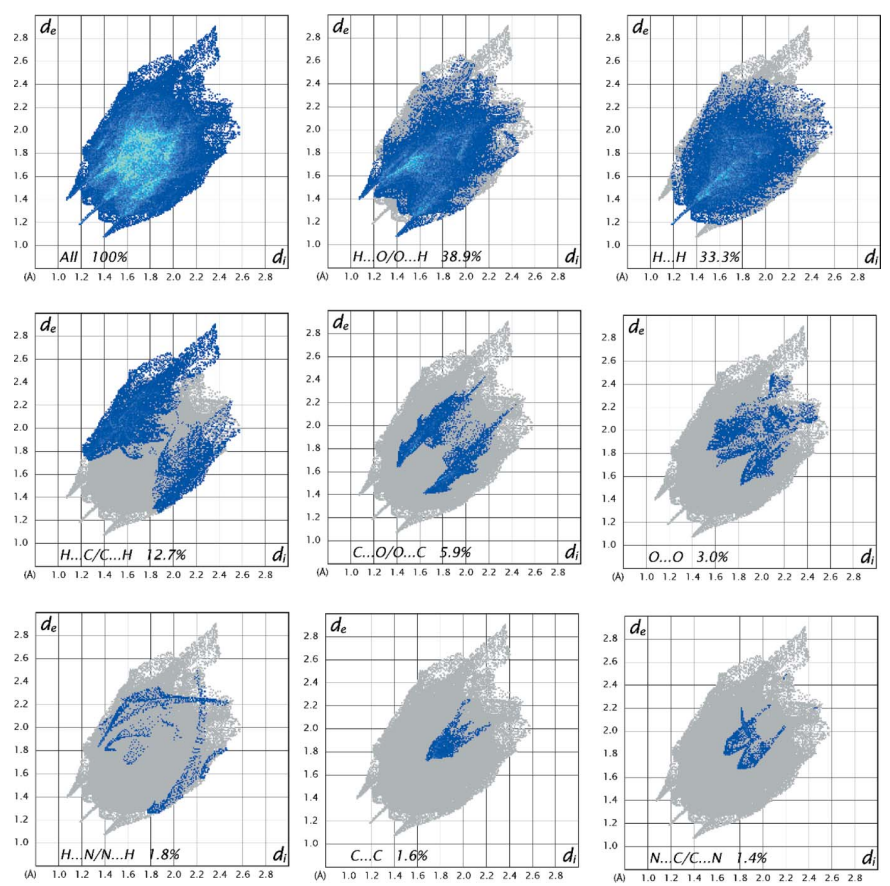

Figure 4

Two-dimensional fingerprint plot of $\left[\mathrm{Cu}_{2}\left(\mathrm{C}_{7} \mathrm{H}_{4} \mathrm{NO}_{4}\right)_{4}\left(\mathrm{C}_{3} \mathrm{H}_{7}\right.\right.$. $\left.\mathrm{NO})_{2}\right] \cdot\left(\mathrm{C}_{3} \mathrm{H}_{7} \mathrm{NO}\right)_{2}$ showing all interactions (top left) and delineated in individual contacts with relative contributions. 
studies (Ibragimov et al., 2021). Input files for the DFT calculations using the ORCA 4.2.0 program package (Neese, 2012) were generated by Avogadro (Hanwell et al., 2012) using the CIF of the title compound. Results of these calculations were analyzed with the aid of Avogadro and Multiwfn (Lu \& Chen, 2012).

Homonuclear $\mathrm{Cu}^{\mathrm{II}}$ complexes form a closed system in which [Ar] $d^{9}$ electrons of two neighbouring $\mathrm{Cu}^{\mathrm{II}}$ cations are paired with each other. Such a system is usually characterized by a singlet ground state. However, triplet and quintet electronic states are also possible, depending on the nature of the ligand molecules. The bond lengths and angles of the complex were therefore fully optimized in the singlet, triplet and quintet electronic spin states with the result that the singlet electronic state was found to be the energetically optimal structure. Calculated and experimentally determined bond lengths and angles are compared in Tables S1 and S2 in the supporting information, and mean absolute errors (MAE), largest errors (LE) and the correlation coefficients $R^{2}$ were determined. The very low values of MAE and LE, and also the high $R^{2}$ coefficient of 0.997 reveal the suitability of the applied method for calculation of the electronic structure parameters of the complex.

Calculations of electron densities on atoms in the highest occupied (HOMO) and lowest unoccupied (LUMO) molecular orbitals (MO), as well as the energies of the frontier MOs (FMO) were carried out. The charge distributions on atoms and on the FMOs, as well as the energy of FMOs are one of the main parameters of the electronic structure of chemical compounds (Karelson et al., 1996; Rauk, 2001; Miar et al., 2021). The energy of the HOMO is related to the electron-donating ability of a molecule and the energy of the LUMO is related to the electron-accepting ability of a molecule. The parameter for chemical hardness $(\eta)$ is calculated based on the HOMO-LUMO energy gap $(\eta=\Delta E / 2)$. The shape of the FMOs and the HOMO-LUMO energy gap of the complex are displayed in Fig. 5. The contribution of both $\mathrm{Cu}^{\mathrm{II}}$ $d$ orbitals in the HOMO and LUMO are $58.14 \%$ and $52.72 \%$, respectively. The contribution of the $p$ orbitals of the eight oxygen atoms of the 3-nitrobenzoate ligands in the HOMO and LUMO are $37.15 \%$ and $38.06 \%$, respectively. A higher contribution of $\mathrm{Cu}^{\mathrm{II}} d$ electrons $(56.74 \%)$ was observed in the case of second occupied MO $\left(E_{\mathrm{HOMO}-1}=-7.0 \mathrm{eV}\right)$, and the next unoccupied MO $\left(E_{\mathrm{LUMO}+1}=-2.74 \mathrm{eV}\right)$ consists of the antibonding $p$ orbitals of the 3-nitrobenzoate fragment.

The complex has a very low HOMO-LUMO energy gap, which can be seen from Fig. 5 and also from the total density of state diagram (TDOS, Fig. S1) of the complex. The low energy gap is caused by a significant decreasing of the energy level of the LUMO of the complex. In other words, the electron accepting ability of the complex is very high and thus the molecule becomes more susceptible to nucleophile attack which makes this complex interesting in chemistry and physics due to its electrical properties and light absorption at a low energy level.

Atomic charge analysis (Fig. S2) shows that the largest negative charges and the largest positive charges are located

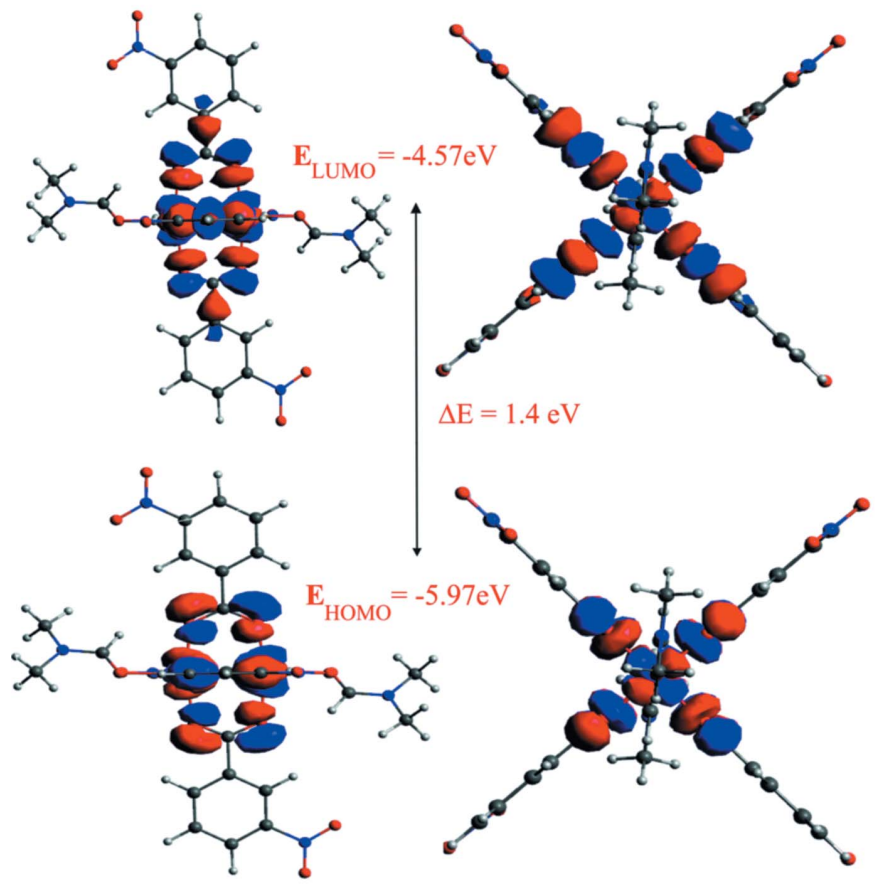

Figure 5

HOMO-LUMO energy diagram of $\left[\mathrm{Cu}_{2}\left(\mathrm{C}_{7} \mathrm{H}_{4} \mathrm{NO}_{4}\right)_{4}\left(\mathrm{C}_{3} \mathrm{H}_{7} \mathrm{NO}\right)_{2}\right] \cdot-$ $\left(\mathrm{C}_{3} \mathrm{H}_{7} \mathrm{NO}\right)_{2}$.

on oxygen atoms and carbon atoms of the carboxylic group, respectively.

\section{FT-IR analysis}

The FT-IR (ATR) spectrum of dimethylformamide (see Fig. S1) comprises the following absorption bands $\left(\mathrm{cm}^{-1}\right)$ : 2926, $2856\left(-\mathrm{CH}, \mathrm{NCH}_{3}\right), 2780(\mathrm{C}-\mathrm{H}, \mathrm{CHO}), 1662(\mathrm{C}=\mathrm{O})$, $1384\left(\mathrm{CH}, \mathrm{NCH}_{3}\right), 1089(\mathrm{C}-\mathrm{N})$. The FTIR (ATR) spectrum of 3-nitrobenzoic acid (Fig. 6) comprises the following absorption bands $\left(\mathrm{cm}^{-1}\right)$ : $3095(\mathrm{C}-\mathrm{H}, \mathrm{Ar}), 2500-3000(\mathrm{OH}$, dimeric form), $1689(\mathrm{C}=\mathrm{O}), 1614,1583$ (Ar), 1525, 1350 ($\left.\mathrm{NO}_{2}\right), 1288(\mathrm{C}-\mathrm{O}, \mathrm{COOH})$. The FTIR (ATR) spectrum of the

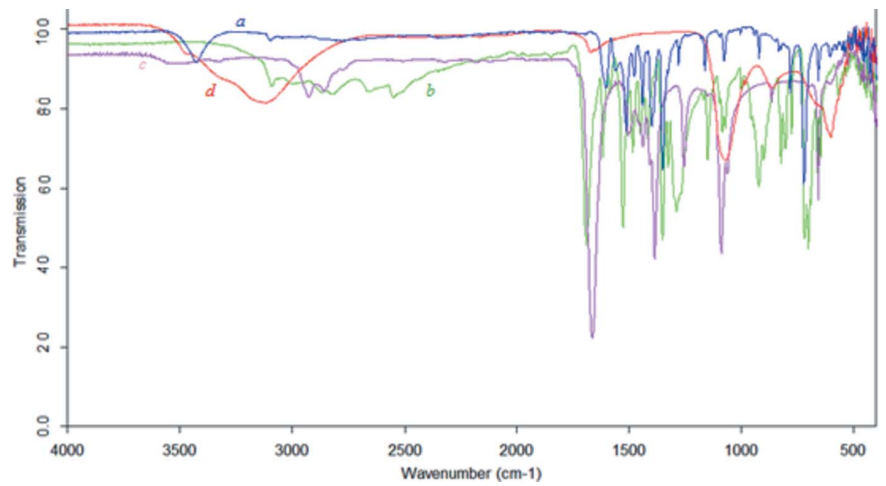

Figure 6

FT-IR (ATR) spectrum of $\left[\mathrm{Cu}_{2}\left(\mathrm{C}_{7} \mathrm{H}_{4} \mathrm{NO}_{4}\right)_{4}\left(\mathrm{C}_{3} \mathrm{H}_{7} \mathrm{NO}\right)_{2}\right] \cdot\left(\mathrm{C}_{3} \mathrm{H}_{7} \mathrm{NO}\right)_{2}(a)$ and the starting compounds 3-nitrobenzoic acid $(b)$, dimethylformamide (c) and aqueous $\mathrm{CuSO}_{4}$ solution (d). 
Table 3

Experimental details.

\begin{tabular}{|c|c|}
\hline \multicolumn{2}{|l|}{ Crystal data } \\
\hline Chemical formula & $\begin{array}{l}{\left[\mathrm{Cu}_{2}\left(\mathrm{C}_{7} \mathrm{H}_{4} \mathrm{NO}_{4}\right)_{4}\left(\mathrm{C}_{3} \mathrm{H}_{7} \mathrm{NO}\right)_{2}\right] \cdot-} \\
\quad 2 \mathrm{C}_{3} \mathrm{H}_{7} \mathrm{NO}\end{array}$ \\
\hline$M_{\mathrm{r}}$ & 1083.91 \\
\hline Crystal system, space group & Monoclinic, $P 2_{1} / c$ \\
\hline Temperature $(\mathrm{K})$ & 293 \\
\hline$a, b, c(\AA)$ & $\begin{array}{l}11.5657(4), 10.4851(3), \\
19.7258(5)\end{array}$ \\
\hline$\beta\left(^{\circ}\right)$ & $91.581(3)$ \\
\hline$V\left(\AA^{3}\right)$ & $2391.19(12)$ \\
\hline$Z$ & 2 \\
\hline Radiation type & $\mathrm{Cu} K \alpha$ \\
\hline$\mu\left(\mathrm{mm}^{-1}\right)$ & 1.84 \\
\hline Crystal size $(\mathrm{mm})$ & $0.20 \times 0.15 \times 0.10$ \\
\hline \multicolumn{2}{|l|}{ Data collection } \\
\hline Diffractometer & Xcalibur, Ruby \\
\hline Absorption correction & $\begin{array}{l}\text { Multi-scan (CrysAlis PRO; Rigaku } \\
\text { OD, 2018) }\end{array}$ \\
\hline$T_{\min }, T_{\max }$ & $0.366,1.000$ \\
\hline $\begin{array}{l}\text { No. of measured, independent and } \\
\text { observed }[I>2 \sigma(I)] \text { reflections }\end{array}$ & $17186,4940,4016$ \\
\hline$R_{\text {int }}$ & 0.041 \\
\hline$(\sin \theta / \lambda)_{\max }\left(\AA^{-1}\right)$ & 0.630 \\
\hline \multicolumn{2}{|l|}{ Refinement } \\
\hline$R\left[F^{2}>2 \sigma\left(F^{2}\right)\right], w R\left(F^{2}\right), S$ & $0.043,0.120,1.05$ \\
\hline No. of reflections & 4940 \\
\hline No. of parameters & 320 \\
\hline H-atom treatment & $\mathrm{H}$-atom parameters constrained \\
\hline$\Delta \rho_{\max }, \Delta \rho_{\min }\left(\mathrm{e} \AA^{-3}\right)$ & $0.38,-0.66$ \\
\hline
\end{tabular}

Computer programs: CrysAlis PRO (Rigaku OD, 2018), SHELXT (Sheldrick, 2015a), SHELXL2014/7 (Sheldrick, 2015b), Mercury (Macrae et al., 2020) and publCIF (Westrip, 2010).

title complex (Fig. 6) comprises the following absorption bands $\left(\mathrm{cm}^{-1}\right)$ : $3095(\mathrm{C}-\mathrm{H}, \mathrm{Ar}), 1600(\mathrm{C}=\mathrm{O}), 1556$ (Ar), $1514,1348\left(-\mathrm{NO}_{2}\right), 1396\left(\mathrm{CH}, \mathrm{NCH}_{3}\right)$.

Analysis of the IR spectra of the starting compounds and the product shows significant changes in the wavenumbers of absorption bands of characteristic groups in the IR spectrum of the product. Upon complexation, some absorption bands disappear, and some of them undergo a high-frequency or lowfrequency shift.

For example, the $\mathrm{C}=\mathrm{O}$ band of 3-nitrobenzoic $\left(1689 \mathrm{~cm}^{-1}\right)$ and dimethylformamide $\left(1662 \mathrm{~cm}^{-1}\right)$ shifts to the lowfrequency region and is observed at $1600 \mathrm{~cm}^{-1}$. Likewise, the absorption band of the nitro group $\left(1525,1350 \mathrm{~cm}^{-1}\right)$ of 3-nitrobenzoic acid is shifted to the low-frequency region $\left(1514,1348 \mathrm{~cm}^{-1}\right)$ after complexation. At the same time, the absorption band of the $-\mathrm{CH}_{3}$ groups of dimethylformamide at $1384 \mathrm{~cm}^{-1}$ undergoes a high-frequency shift and is observed at $1396 \mathrm{~cm}^{-1}$. On the other hand, the absorption band of the $\mathrm{C}-\mathrm{O}$ group at $1288 \mathrm{~cm}^{-1}$ of 3-nitrobenzoic acid does not occur in the IR spectrum of the complex.

\section{Database survey}

A search of the Cambridge Structural Database (CSD, Version 2020.1 including the update of January 2020; Groom et al., 2016) of binuclear copper(II) complexes comprising benzoate ligands with an $o$-nitro group gave nine hits, with an $m$-nitro group gave four hits [FAZXUA (Kabbani et al., 2004), KELXEF (Stachová et al., 2006), NIDSEY (Hökelek et al., 1998) and PABNEP (Xu et al., 2020)], and with a $p$-nitro group also gave four hits [AQNBCU (Usubaliev et al., 1980), BOVPIN (Jassal et al., 2015), QIXQIX01 (Li \& Zhou, 2010) and VIHNAD (Song et al., 2013)]. In the dinitrobenzoate complex NIDSEY, $\left[\mathrm{Cu}_{3}\left\{\left(\mathrm{NO}_{2}\right)_{2} \mathrm{C}_{6} \mathrm{H}_{3} \mathrm{COO}_{6}\left(\mathrm{CH}_{3}-\mathrm{OH}\right)_{2}\right]\right.$, comprising three copper(II) atoms, two of them are fivecoordinate, being surrounded by square-pyramids of carboxylate $\mathrm{O}$ atoms and forming a paddle-wheel-shaped binuclear structure, whereas the third copper(II) ion has a square-planar environment.

\section{Synthesis and crystallization}

The crystals were grown from low-cost standard materials. 3-Nitrobenzoic acid $(20.0 \mathrm{mg}, 0.12 \mathrm{mmol})$ and $\mathrm{CuSO}_{4} \cdot 5 \mathrm{H}_{2} \mathrm{O}$ $(20 \mathrm{mg}, 0.056 \mathrm{mmol})$ were mixed and stirred at room temperature for $1 \mathrm{~h}$. Then, in a gradual way, dimethylformamide (DMF; $0.78 \mathrm{mmol}$ ) was added dropwise to the stirred mixture throughout $60 \mathrm{~min}$ at $303 \mathrm{~K}$, immediately after which the solution was cooled down and kept for several hours. Darkish blue single crystals suitable for X-ray analysis were grown by slow evaporation at ambient temperature for one week and collected by filtration. They were finally washed with pure DMF. Yield: $70 \%$.

\section{Refinement}

Crystal data, data collection and structure refinement details are summarized in Table 3. Hydrogen atoms bonded to carbon atoms were placed in calculated positions and refined to ride on their parent atoms with $\mathrm{C}-\mathrm{H}=0.93 \AA$ and $U_{\text {iso }}(\mathrm{H})=$ $1.2 U_{\text {eq }}(\mathrm{C})$ for aromatic hydrogen atoms, and with $\mathrm{C}-\mathrm{H}=$ $0.96 \AA$ and $U_{\text {iso }}(\mathrm{H})=1.5 U_{\text {eq }}(\mathrm{C})$ for methyl hydrogen atoms.

\section{Funding information}

Funding for this research was provided by: This work was supported by a Grant for Fundamental Research from the Center of Science and Technology, Uzbekistan (No. BA-FAF7-004).

\section{References}

Becke, A. D. (1988). Phys. Rev. A, 38, 3098-3100.

Drożdżewski, P., Brożyna, A. \& Kubiak, M. (2004). Polyhedron, 23, 1785-1792.

Groom, C. R., Bruno, I. J., Lightfoot, M. P. \& Ward, S. C. (2016). Acta Cryst. B72, 171-179.

Haiduc, I. \& Silvestru, C. (1989). Organometallics in Cancer Chemotherapy. Boston: CRS, Press.

Hanwell, M. D., Curtis, D. E., Lonie, D. C., Vandermeersch, T., Zurek, E. \& Hutchison, G. R. (2012). J. Cheminform, 4, 1-17.

Harrison, W., Rettig, S. \& Trotter, J. J. (1972). J. Chem. Soc. Dalton Trans. pp. 1852-1856.

Hökelek, T., Mert, Y. \& Ünalerouğlu, C. (1998). Acta Cryst. C54, 310313.

Ibragimov, A. B., Ashurov, J. M., Ibragimov, A. B. \& Eshimbetov, A. G. (2021). J. Chem. Crystallogr. 51, 405-417. 
Jassal, A. K., Sharma, S., Hundal, G. \& Hundal, M. S. (2015). Cryst. Growth Des. 15, 79-93.

Kabbani, A. T., Zaworotko, M. J., Abourahma, H., Walsh, R. D. B. \& Hammud, H. H. (2004). J. Chem. Crystallogr. 34, 749-756.

Karelson, M., Lobanov, V. S. \& Katritzky, A. R. (1996). Chem. Rev. 96, 1027-1044.

Lee, C., Yang, W. \& Parr, G. (1988). Phys. Rev. B, 37, 785-789.

Li, J. \& Zhou, H. (2010). Nat. Chem. 2, 893-898.

Linder, M. C. \& Goode, C. A. (1991). Biochemistry of Copper. New York: Plenum.

Lu, T. \& Chen, F. (2012). J. Comput. Chem. 33, 580-592.

Macrae, C. F., Sovago, I., Cottrell, S. J., Galek, P. T. A., McCabe, P., Pidcock, E., Platings, M., Shields, G. P., Stevens, J. S., Towler, M. \& Wood, P. A. (2020). J. Appl. Cryst. 53, 226-235.

Miar, M., Shiroudi, A., Pourshamsian, K., Oliaey, A. R. \& Hatamjafari, F. (2021). J. Chem. Res. 45, 147-158.

Neese, F. (2012). WIREs Comput. Mol. Sci. 2, 73-78.

Niekerk, J. N. van \& Schoening, F. R. L. (1953). Acta Cryst. 6, 227232.

Rao, V. M., Sathyanarayana, D. N. \& Manohar, H. J. (1983). J. Chem. Soc. Dalton Trans. pp. 2167-2173.

Rauk, A. (2001). Orbital interaction. Theory of Organic Chemistry. New York: Wiley-Interscience.
Rigaku OD (2018). CrysAlis PRO. Rigaku OD, Yarnton, England. Sheldrick, G. M. (2015a). Acta Cryst. A71, 3-8.

Sheldrick, G. M. (2015b). Acta Cryst. C71, 3-8.

Song, S., Cui, J., Li, Z. \& Nie, F. (2013). Z. Krist. New Cryst. Struct. 228, 199-200.

Stachová, P., Moncol, J., Valigura, D. \& Lis, T. (2006). Acta Cryst. C62, m375-m377.

Su, F., Lu, L., Feng, S., Zhu, M., Gao, Z. \& Dong, Y. (2015). Dalton Trans. 44, 7213-7222.

Tapiero, H. \& Tew, K. D. (2003). Biomed. Pharmacother. 57, 399-411.

Turner, M. J., McKinnon, J. J., Wolff, S. K., Grimwood, D. J., Spackman, P. R., Jayatilaka, D. \& Spackman, M. A. (2017). Crystal Explorer 17.5. The University of Western Australia.

Ueyama, N., Yamada, Y., Takeda, J., Okamura, T., Mori, W. \& Nakamura, A. (1996). Chem. Commun. pp. 1377-1378.

Usubaliev, B. T., Movsumov, E. M., Amiraslanov, I. R. \& Mamedov, Kh. S. (1980). Dokl. Nat. Akad. Nauk Azerbauidzhana, 36, 40.

Wang, J., Su, F. \& Shi, L. (2018). Acta Cryst. E74, 691-694.

Westrip, S. P. (2010). J. Appl. Cryst. 43, 920-925.

$\mathrm{Xu}, \mathrm{D}$., Gao, J. \& Long, S. (2020). IUCrData, 5, x200801.

Zhu, L.-G., Kitagawa, S., Miyasaka, H. \& Chang, H.-C. (2003). Inorg. Chim. Acta, 355, 121-126. 


\section{supporting information}

Acta Cryst. (2021). E77, 1164-1169 [https://doi.org/10.1107/S2056989021010999]

Crystal structure, Hirshfeld surface analysis and DFT studies of tetrakis $(\mu-3-$ nitrobenzoato- $\left.\kappa^{2} O^{1}: O^{1}\right)$ bis $[(N, N$-dimethylformamide- $\kappa O)$ copper(II)] dimethylformamide disolvate

Mavlonbek A. Ziyaev, Jamshid M. Ashurov, Alisher G. Eshimbetov and Bakhtiyar T. Ibragimov

Computing details

Data collection: CrysAlis PRO (Rigaku OD, 2018); cell refinement: CrysAlis PRO (Rigaku OD, 2018); data reduction: CrysAlis PRO (Rigaku OD, 2018); program(s) used to solve structure: SHELXT (Sheldrick, 2015a); program(s) used to refine structure: SHELXL2014/7 (Sheldrick, 2015b); molecular graphics: Mercury (Macrae et al., 2020); software used to prepare material for publication: publCIF (Westrip, 2010).

Tetrakis( $\mu$-3-nitrobenzoato- $\left.\kappa^{2} O^{1}: O^{1}\right)$ bis $[(N, N$-dimethylformamide- $\kappa O) \operatorname{copper}(I I)]$ dimethylformamide disolvate

Crystal data

$\left[\mathrm{Cu}_{2}\left(\mathrm{C}_{7} \mathrm{H}_{4} \mathrm{NO}_{4}\right)_{4}\left(\mathrm{C}_{3} \mathrm{H}_{7} \mathrm{NO}\right)_{2}\right] \cdot 2 \mathrm{C}_{3} \mathrm{H}_{7} \mathrm{NO}$

$M_{r}=1083.91$

Monoclinic, $P 2_{1} / c$

$a=11.5657$ (4) $\AA$

$b=10.4851(3) \AA$

$c=19.7258(5) \AA$

$\beta=91.581(3)^{\circ}$

$V=2391.19(12) \AA^{3}$

$Z=2$

$$
F(000)=1116
$$

$D_{\mathrm{x}}=1.505 \mathrm{Mg} \mathrm{m}^{-3}$

$\mathrm{Cu} K \alpha$ radiation, $\lambda=1.54184 \AA$

Cell parameters from 5941 reflections

$\theta=4.2-75.5^{\circ}$

$\mu=1.84 \mathrm{~mm}^{-1}$

$T=293 \mathrm{~K}$

Plate, blue

$0.20 \times 0.15 \times 0.10 \mathrm{~mm}$

Data collection

Xcalibur, Ruby diffractometer

Radiation source: Enhance (Cu) X-ray Source

Graphite monochromator

Detector resolution: 10.2576 pixels $\mathrm{mm}^{-1}$

w $\sigma$ cans

Absorption correction: multi-scan

(CrysAlisPro; Rigaku OD, 2018)

$T_{\min }=0.366, T_{\max }=1.000$

17186 measured reflections

4940 independent reflections

4016 reflections with $I>2 \sigma(I)$

$R_{\text {int }}=0.041$

$\theta_{\max }=76.2^{\circ}, \theta_{\min }=3.8^{\circ}$

$h=-14 \rightarrow 14$

$k=-13 \rightarrow 12$

$l=-24 \rightarrow 16$

Refinement

Refinement on $F^{2}$

Least-squares matrix: full

$R\left[F^{2}>2 \sigma\left(F^{2}\right)\right]=0.043$

$w R\left(F^{2}\right)=0.120$

$S=1.05$

4940 reflections

320 parameters

0 restraints

Primary atom site location: structure-invariant direct methods

Hydrogen site location: inferred from neighbouring sites

$\mathrm{H}$-atom parameters constrained 
$w=1 /\left[\sigma^{2}\left(F_{\mathrm{o}}^{2}\right)+(0.0582 P)^{2}+0.9153 P\right]$

where $P=\left(F_{\mathrm{o}}^{2}+2 F_{\mathrm{c}}^{2}\right) / 3$

$(\Delta / \sigma)_{\max }=0.001$

$$
\Delta \rho_{\max }=0.38 \text { e } \AA^{-3}
$$

$\Delta \rho_{\min }=-0.65$ e $\AA^{-3}$

Special details

Geometry. All esds (except the esd in the dihedral angle between two 1.s. planes) are estimated using the full covariance matrix. The cell esds are taken into account individually in the estimation of esds in distances, angles and torsion angles; correlations between esds in cell parameters are only used when they are defined by crystal symmetry. An approximate (isotropic) treatment of cell esds is used for estimating esds involving 1.s. planes.

Fractional atomic coordinates and isotropic or equivalent isotropic displacement parameters $\left(\AA^{2}\right)$

\begin{tabular}{|c|c|c|c|c|}
\hline & $x$ & $y$ & $z$ & $U_{\text {iso }} * / U_{\text {eq }}$ \\
\hline $\mathrm{Cu} 1$ & $0.52536(3)$ & $0.37834(3)$ & $0.48912(2)$ & $0.03259(12)$ \\
\hline $\mathrm{O} 1$ & $0.67889(15)$ & $0.43281(17)$ & $0.52255(9)$ & 0.0438 \\
\hline $\mathrm{O} 2$ & $0.63778(15)$ & $0.63846(16)$ & $0.54126(9)$ & $0.0442(4)$ \\
\hline $\mathrm{O} 3$ & $0.48321(16)$ & $0.35248(16)$ & $0.58396(8)$ & $0.0447(4)$ \\
\hline $\mathrm{O} 4$ & $0.43655(16)$ & $0.55704(16)$ & $0.60163(8)$ & $0.0438(4)$ \\
\hline O5 & $0.57752(17)$ & $0.18687(16)$ & $0.46685(9)$ & $0.0474(4)$ \\
\hline O6 & $0.2420(2)$ & $0.6543(3)$ & $0.81319(13)$ & $0.0853(8)$ \\
\hline $\mathrm{O} 7$ & $0.2426(3)$ & $0.5167(3)$ & $0.89371(12)$ & $0.0977(10)$ \\
\hline O8 & $1.1930(2)$ & $0.3843(3)$ & $0.60860(15)$ & $0.0927(9)$ \\
\hline O9 & $1.0475(2)$ & $0.2614(3)$ & $0.59089(17)$ & $0.1004(10)$ \\
\hline N1 & $0.7192(2)$ & $0.0413(2)$ & $0.45278(11)$ & $0.0533(6)$ \\
\hline N2 & $0.2717(2)$ & $0.5527(3)$ & $0.83778(12)$ & $0.0612(7)$ \\
\hline N3 & $1.0906(2)$ & $0.3660(3)$ & $0.59792(14)$ & $0.0659(8)$ \\
\hline $\mathrm{C} 1$ & $0.4512(2)$ & $0.4433(2)$ & $0.62026(11)$ & $0.0376(5)$ \\
\hline $\mathrm{C} 2$ & $0.4313(2)$ & $0.4157(2)$ & $0.69403(11)$ & $0.0376(5)$ \\
\hline $\mathrm{C} 3$ & $0.4849(3)$ & $0.3128(3)$ & $0.72534(13)$ & $0.0509(7)$ \\
\hline H3 & 0.5305 & 0.2581 & 0.7004 & $0.061^{*}$ \\
\hline $\mathrm{C} 4$ & $0.4709(3)$ & $0.2912(3)$ & $0.79400(15)$ & $0.0614(8)$ \\
\hline $\mathrm{H} 4$ & 0.5092 & 0.2233 & 0.8150 & $0.074^{*}$ \\
\hline $\mathrm{C} 5$ & $0.4012(3)$ & $0.3685(3)$ & $0.83118(13)$ & $0.0543(7)$ \\
\hline H5 & 0.3909 & 0.3534 & 0.8771 & $0.065^{*}$ \\
\hline C6 & $0.3469(2)$ & $0.4689(3)$ & $0.79880(12)$ & $0.0445(6)$ \\
\hline $\mathrm{C} 7$ & $0.3616(2)$ & $0.4953(2)$ & $0.73090(12)$ & $0.0411(6)$ \\
\hline $\mathrm{H} 7$ & 0.3253 & 0.5651 & 0.7105 & $0.049^{*}$ \\
\hline $\mathrm{C} 8$ & $0.7049(2)$ & $0.5442(2)$ & $0.54082(11)$ & $0.0373(5)$ \\
\hline C9 & $0.8275(2)$ & $0.5637(2)$ & $0.56579(12)$ & $0.0398(5)$ \\
\hline $\mathrm{C} 10$ & $0.8687(3)$ & $0.6832(3)$ & $0.58268(15)$ & $0.0547(7)$ \\
\hline $\mathrm{H} 10$ & 0.8197 & 0.7534 & 0.5794 & $0.066^{*}$ \\
\hline $\mathrm{C} 11$ & $0.9830(3)$ & $0.6997(3)$ & $0.60457(18)$ & $0.0701(9)$ \\
\hline H11 & 1.0098 & 0.7807 & 0.6161 & $0.084^{*}$ \\
\hline $\mathrm{C} 12$ & $1.0562(3)$ & $0.5977(3)$ & $0.60927(17)$ & $0.0654(9)$ \\
\hline $\mathrm{H} 12$ & 1.1332 & 0.6084 & 0.6231 & $0.078^{*}$ \\
\hline $\mathrm{C} 13$ & $1.0132(2)$ & $0.4784(3)$ & $0.59303(14)$ & $0.0504(7)$ \\
\hline $\mathrm{C} 14$ & $0.9006(2)$ & $0.4592(3)$ & $0.57205(12)$ & $0.0449(6)$ \\
\hline H14 & 0.8736 & 0.3776 & 0.5622 & $0.054 *$ \\
\hline $\mathrm{C} 15$ & 0.6799 & $0.1556(3)$ & $0.46790(13)$ & $0.0482(6)$ \\
\hline
\end{tabular}




$\begin{array}{lllll}\text { H15 } & 0.7341 & 0.2174 & 0.4803 & 0.058^{*} \\ \text { C16 } & 0.6410(4) & -0.0611(3) & 0.4369(2) & 0.0850(12) \\ \text { H16A } & 0.6331 & -0.1143 & 0.4761 & 0.128^{*} \\ \text { H16B } & 0.6707 & -0.1107 & 0.4004 & 0.128^{*} \\ \text { H16C } & 0.5668 & -0.0268 & 0.4236 & 0.128^{*} \\ \text { C17 } & 0.8432(3) & 0.0129(4) & 0.4595(2) & 0.0837(12) \\ \text { H17A } & 0.8833 & 0.0858 & 0.4779 & 0.126^{*} \\ \text { H17B } & 0.8726 & -0.0069 & 0.4157 & 0.126^{*} \\ \text { H17C } & 0.8548 & -0.0587 & 0.4892 & 0.126^{*} \\ \text { O10 } & 1.0396(3) & 0.4379(4) & 0.7733(2) & 0.1376(14) \\ \text { N4 } & 0.8658(3) & 0.5366(3) & 0.76200(16) & 0.0773(8) \\ \text { C18 } & 0.9808(5) & 0.5333(5) & 0.7716(2) & 0.0941(13) \\ \text { H18 } & 1.0188 & 0.6109 & 0.7774 & 0.113^{*} \\ \text { C19 } & 0.8031(6) & 0.4220(6) & 0.7556(3) & 0.145(2) \\ \text { H19A } & 0.8554 & 0.3532 & 0.7469 & 0.217^{*} \\ \text { H19B } & 0.7477 & 0.4292 & 0.7187 & 0.217^{*} \\ \text { H19C } & 0.7636 & 0.4056 & 0.7968 & 0.217^{*} \\ \text { C20 } & 0.8067(5) & 0.6575(5) & 0.7589(2) & 0.1113(16) \\ \text { H20A } & 0.7587 & 0.6661 & 0.7976 & 0.167^{*} \\ \text { H20B } & 0.7594 & 0.6616 & 0.7182 & 0.167^{*} \\ \text { H20C } & 0.8624 & 0.7253 & 0.7589 & 0.167^{*} \\ & & & & \end{array}$

Atomic displacement parameters $\left(\AA^{2}\right)$

\begin{tabular}{|c|c|c|c|c|c|c|}
\hline & $U^{11}$ & $U^{22}$ & $U^{33}$ & $U^{12}$ & $U^{13}$ & $U^{23}$ \\
\hline $\mathrm{Cu} 1$ & $0.0397(2)$ & 0.02672 (19) & $0.03118(18)$ & $0.00108(14)$ & $-0.00230(14)$ & $-0.00110(12)$ \\
\hline $\mathrm{O} 1$ & $0.0408(10)$ & $0.0382(9)$ & $0.0517(10)$ & $0.0001(8)$ & $-0.0074(8)$ & $-0.0067(8)$ \\
\hline $\mathrm{O} 2$ & $0.0428(10)$ & $0.0384(10)$ & $0.0511(10)$ & $0.0009(8)$ & $-0.0070(8)$ & $-0.0056(8)$ \\
\hline $\mathrm{O} 3$ & $0.0604(12)$ & $0.0393(10)$ & $0.0346(8)$ & $0.0024(8)$ & $0.0043(8)$ & $0.0023(7)$ \\
\hline $\mathrm{O} 4$ & $0.0626(12)$ & $0.0360(9)$ & $0.0328(8)$ & $-0.0022(8)$ & $0.0026(8)$ & $0.0038(7)$ \\
\hline O5 & $0.0572(12)$ & $0.0315(9)$ & $0.0533(10)$ & $0.0070(8)$ & $0.0008(9)$ & $-0.0047(8)$ \\
\hline O6 & $0.108(2)$ & $0.0639(15)$ & $0.0859(17)$ & $0.0257(15)$ & $0.0341(15)$ & $0.0078(13)$ \\
\hline $\mathrm{O} 7$ & $0.125(2)$ & $0.122(2)$ & $0.0477(13)$ & 0.0305 (19) & $0.0330(14)$ & $0.0112(14)$ \\
\hline O8 & $0.0399(13)$ & $0.133(3)$ & $0.105(2)$ & $0.0118(14)$ & $-0.0095(13)$ & $0.0151(17)$ \\
\hline O9 & $0.0694(17)$ & $0.0748(18)$ & $0.156(3)$ & $0.0204(15)$ & $-0.0189(17)$ & $-0.0202(19)$ \\
\hline N1 & $0.0728(17)$ & $0.0353(12)$ & $0.0528(13)$ & $0.0130(11)$ & $0.0181(12)$ & $0.0010(10)$ \\
\hline N2 & $0.0669(17)$ & $0.0692(18)$ & $0.0480(13)$ & $0.0005(14)$ & $0.0093(12)$ & $-0.0031(13)$ \\
\hline N3 & $0.0449(16)$ & $0.089(2)$ & $0.0635(16)$ & $0.0140(15)$ & $-0.0027(12)$ & $0.0034(15)$ \\
\hline $\mathrm{C} 1$ & 0.0405 (13) & $0.0390(13)$ & $0.0330(11)$ & $-0.0051(11)$ & $-0.0030(9)$ & $0.0045(10)$ \\
\hline $\mathrm{C} 2$ & 0.0425 (14) & $0.0361(12)$ & $0.0339(11)$ & $-0.0029(11)$ & $-0.0014(10)$ & $0.0042(9)$ \\
\hline $\mathrm{C} 3$ & $0.0568(17)$ & $0.0503(16)$ & $0.0456(14)$ & 0.0095 (14) & $0.0034(12)$ & $0.0074(12)$ \\
\hline $\mathrm{C} 4$ & $0.074(2)$ & $0.062(2)$ & $0.0476(15)$ & 0.0153 (17) & $-0.0003(14)$ & $0.0188(14)$ \\
\hline $\mathrm{C} 5$ & $0.0636(19)$ & 0.0632 (19) & $0.0359(13)$ & $0.0016(15)$ & $0.0001(12)$ & $0.0138(12)$ \\
\hline C6 & $0.0498(15)$ & $0.0479(15)$ & $0.0361(12)$ & $-0.0027(12)$ & $0.0035(11)$ & $0.0015(11)$ \\
\hline $\mathrm{C} 7$ & $0.0435(14)$ & $0.0391(14)$ & $0.0404(12)$ & $-0.0016(11)$ & $-0.0025(10)$ & $0.0076(10)$ \\
\hline $\mathrm{C} 8$ & 0.0409 (13) & $0.0399(13)$ & $0.0310(11)$ & $-0.0013(11)$ & $-0.0013(9)$ & $0.0010(9)$ \\
\hline C9 & $0.0402(14)$ & $0.0434(14)$ & $0.0357(11)$ & $-0.0029(11)$ & $-0.0014(10)$ & $-0.0003(10)$ \\
\hline $\mathrm{C} 10$ & $0.0547(17)$ & $0.0478(16)$ & $0.0610(17)$ & $-0.0100(14)$ & $-0.0097(14)$ & 0.0025 (13) \\
\hline
\end{tabular}




\begin{tabular}{lllllll}
$\mathrm{C} 11$ & $0.065(2)$ & $0.059(2)$ & $0.085(2)$ & $-0.0241(17)$ & $-0.0192(18)$ & $0.0027(17)$ \\
$\mathrm{C} 12$ & $0.0466(18)$ & $0.081(2)$ & $0.0672(19)$ & $-0.0181(17)$ & $-0.0165(15)$ & $0.0062(17)$ \\
$\mathrm{C} 13$ & $0.0398(14)$ & $0.0673(19)$ & $0.0438(13)$ & $0.0021(14)$ & $-0.0017(11)$ & $0.0014(13)$ \\
$\mathrm{C} 14$ & $0.0411(14)$ & $0.0527(16)$ & $0.0409(13)$ & $-0.0042(12)$ & $-0.0018(11)$ & $-0.0046(11)$ \\
$\mathrm{C} 15$ & $0.0596(18)$ & $0.0360(14)$ & $0.0494(14)$ & $0.0068(13)$ & $0.0075(13)$ & $-0.0021(11)$ \\
$\mathrm{C} 16$ & $0.110(3)$ & $0.0401(18)$ & $0.107(3)$ & $0.0039(19)$ & $0.027(2)$ & $-0.0158(19)$ \\
$\mathrm{C} 17$ & $0.085(3)$ & $0.072(2)$ & $0.096(3)$ & $0.034(2)$ & $0.034(2)$ & $0.008(2)$ \\
O10 & $0.140(3)$ & $0.109(3)$ & $0.163(4)$ & $0.049(3)$ & $-0.008(3)$ & $0.016(3)$ \\
$\mathrm{N} 4$ & $0.086(2)$ & $0.072(2)$ & $0.0730(19)$ & $-0.0017(18)$ & $0.0054(16)$ & $0.0005(16)$ \\
C18 & $0.107(4)$ & $0.085(3)$ & $0.090(3)$ & $0.008(3)$ & $0.004(3)$ & $0.006(2)$ \\
C19 & $0.179(6)$ & $0.133(5)$ & $0.122(4)$ & $-0.071(5)$ & $0.000(4)$ & $-0.009(4)$ \\
C20 & $0.117(4)$ & $0.120(4)$ & $0.097(3)$ & $0.040(3)$ & $0.014(3)$ & $0.009(3)$ \\
& & & & & & \\
\hline
\end{tabular}

Geometric parameters $\left(\AA,{ }^{\circ}\right)$

\begin{tabular}{|c|c|c|c|}
\hline $\mathrm{Cu} 1-\mathrm{O} 1$ & $1.9620(17)$ & $\mathrm{C} 6-\mathrm{C} 7$ & $1.383(3)$ \\
\hline $\mathrm{Cu} 1-\mathrm{O} 3$ & $1.9650(16)$ & $\mathrm{C} 7-\mathrm{H} 7$ & 0.9300 \\
\hline $\mathrm{Cu} 1-\mathrm{O} 2^{\mathrm{i}}$ & $1.9719(18)$ & $\mathrm{C} 8-\mathrm{C} 9$ & $1.502(3)$ \\
\hline $\mathrm{Cu} 1-\mathrm{O} 4^{\mathrm{i}}$ & $1.9751(16)$ & $\mathrm{C} 9-\mathrm{C} 10$ & $1.378(4)$ \\
\hline $\mathrm{Cu} 1-\mathrm{O} 5$ & $2.1453(17)$ & $\mathrm{C} 9-\mathrm{C} 14$ & $1.387(4)$ \\
\hline $\mathrm{Cu} 1-\mathrm{Cu} 1^{\mathrm{i}}$ & $2.6554(6)$ & $\mathrm{C} 10-\mathrm{C} 11$ & $1.390(4)$ \\
\hline $\mathrm{O} 1-\mathrm{C} 8$ & $1.257(3)$ & $\mathrm{C} 10-\mathrm{H} 10$ & 0.9300 \\
\hline $\mathrm{O} 2-\mathrm{C} 8$ & $1.257(3)$ & $\mathrm{C} 11-\mathrm{C} 12$ & $1.365(5)$ \\
\hline $\mathrm{O} 2-\mathrm{Cu} 1^{\mathrm{i}}$ & $1.9718(18)$ & $\mathrm{C} 11-\mathrm{H} 11$ & 0.9300 \\
\hline $\mathrm{O} 3-\mathrm{C} 1$ & $1.254(3)$ & $\mathrm{C} 12-\mathrm{C} 13$ & $1.381(4)$ \\
\hline $\mathrm{O} 4-\mathrm{C} 1$ & $1.258(3)$ & $\mathrm{C} 12-\mathrm{H} 12$ & 0.9300 \\
\hline $\mathrm{O} 4-\mathrm{Cu} 1^{\mathrm{i}}$ & $1.9751(16)$ & $\mathrm{C} 13-\mathrm{C} 14$ & $1.371(4)$ \\
\hline $\mathrm{O} 5-\mathrm{C} 15$ & $1.229(3)$ & $\mathrm{C} 14-\mathrm{H} 14$ & 0.9300 \\
\hline $\mathrm{O} 6-\mathrm{N} 2$ & $1.216(3)$ & $\mathrm{C} 15-\mathrm{H} 15$ & 0.9300 \\
\hline $\mathrm{O} 7-\mathrm{N} 2$ & $1.222(3)$ & C16-H16A & 0.9600 \\
\hline $\mathrm{O} 8-\mathrm{N} 3$ & $1.213(3)$ & C16-H16B & 0.9600 \\
\hline O9-N3 & $1.211(4)$ & $\mathrm{C} 16-\mathrm{H} 16 \mathrm{C}$ & 0.9600 \\
\hline $\mathrm{N} 1-\mathrm{C} 15$ & $1.318(3)$ & C17-H17A & 0.9600 \\
\hline $\mathrm{N} 1-\mathrm{C} 16$ & $1.432(4)$ & C17-H17B & 0.9600 \\
\hline $\mathrm{N} 1-\mathrm{C} 17$ & $1.467(4)$ & $\mathrm{C} 17-\mathrm{H} 17 \mathrm{C}$ & 0.9600 \\
\hline N2-C6 & $1.469(4)$ & $\mathrm{O} 10-\mathrm{C} 18$ & $1.209(5)$ \\
\hline $\mathrm{N} 3-\mathrm{C} 13$ & $1.481(4)$ & $\mathrm{N} 4-\mathrm{C} 18$ & $1.339(6)$ \\
\hline $\mathrm{C} 1-\mathrm{C} 2$ & $1.508(3)$ & $\mathrm{N} 4-\mathrm{C} 19$ & $1.407(6)$ \\
\hline $\mathrm{C} 2-\mathrm{C} 3$ & $1.381(4)$ & $\mathrm{N} 4-\mathrm{C} 20$ & $1.441(5)$ \\
\hline $\mathrm{C} 2-\mathrm{C} 7$ & $1.381(3)$ & $\mathrm{C} 18-\mathrm{H} 18$ & 0.9300 \\
\hline $\mathrm{C} 3-\mathrm{C} 4$ & $1.387(4)$ & C19-H19A & 0.9600 \\
\hline $\mathrm{C} 3-\mathrm{H} 3$ & 0.9300 & C19-H19B & 0.9600 \\
\hline $\mathrm{C} 4-\mathrm{C} 5$ & $1.370(4)$ & $\mathrm{C} 19-\mathrm{H} 19 \mathrm{C}$ & 0.9600 \\
\hline $\mathrm{C} 4-\mathrm{H} 4$ & 0.9300 & $\mathrm{C} 20-\mathrm{H} 20 \mathrm{~A}$ & 0.9600 \\
\hline $\mathrm{C} 5-\mathrm{C} 6$ & $1.374(4)$ & $\mathrm{C} 20-\mathrm{H} 20 \mathrm{~B}$ & 0.9600 \\
\hline $\mathrm{C} 5-\mathrm{H} 5$ & 0.9300 & $\mathrm{C} 20-\mathrm{H} 20 \mathrm{C}$ & 0.9600 \\
\hline $\mathrm{O} 1-\mathrm{Cu} 1-\mathrm{O} 3$ & $88.06(8)$ & $\mathrm{O} 1-\mathrm{C} 8-\mathrm{C} 9$ & $115.9(2)$ \\
\hline
\end{tabular}




\begin{tabular}{|c|c|c|c|}
\hline $\mathrm{O} 1-\mathrm{Cu} 1-\mathrm{O} 2^{\mathrm{i}}$ & $167.89(7)$ & $\mathrm{C} 10-\mathrm{C} 9-\mathrm{C} 14$ & $119.4(2)$ \\
\hline $\mathrm{O} 3-\mathrm{Cu} 1-\mathrm{O} 2^{\mathrm{i}}$ & $90.95(8)$ & $\mathrm{C} 10-\mathrm{C} 9-\mathrm{C} 8$ & $121.3(2)$ \\
\hline $\mathrm{O} 1-\mathrm{Cu} 1-\mathrm{O} 4^{\mathrm{i}}$ & $88.98(8)$ & $\mathrm{C} 14-\mathrm{C} 9-\mathrm{C} 8$ & $119.3(2)$ \\
\hline $\mathrm{O} 3-\mathrm{Cu} 1-\mathrm{O} 4^{\mathrm{i}}$ & $167.85(7)$ & $\mathrm{C} 9-\mathrm{C} 10-\mathrm{C} 11$ & $120.5(3)$ \\
\hline $\mathrm{O} 2^{\mathrm{i}}-\mathrm{Cu} 1-\mathrm{O} 4^{\mathrm{i}}$ & $89.47(8)$ & $\mathrm{C} 9-\mathrm{C} 10-\mathrm{H} 10$ & 119.7 \\
\hline $\mathrm{O} 1-\mathrm{Cu} 1-\mathrm{O} 5$ & $94.83(7)$ & $\mathrm{C} 11-\mathrm{C} 10-\mathrm{H} 10$ & 119.7 \\
\hline $\mathrm{O} 3-\mathrm{Cu} 1-\mathrm{O} 5$ & $98.30(7)$ & $\mathrm{C} 12-\mathrm{C} 11-\mathrm{C} 10$ & $120.4(3)$ \\
\hline $\mathrm{O} 2 \mathrm{i}-\mathrm{Cu} 1-\mathrm{O} 5$ & $97.26(7)$ & $\mathrm{C} 12-\mathrm{C} 11-\mathrm{H} 11$ & 119.8 \\
\hline $\mathrm{O} 4-\mathrm{Cu} 1-\mathrm{O} 5$ & $93.69(7)$ & $\mathrm{C} 10-\mathrm{C} 11-\mathrm{H} 11$ & 119.8 \\
\hline $\mathrm{O} 1-\mathrm{Cu} 1-\mathrm{Cu} 1^{\mathrm{i}}$ & $82.41(5)$ & $\mathrm{C} 11-\mathrm{C} 12-\mathrm{C} 13$ & $118.4(3)$ \\
\hline $\mathrm{O} 3-\mathrm{Cu} 1-\mathrm{Cu} 1^{\mathrm{i}}$ & $85.24(5)$ & $\mathrm{C} 11-\mathrm{C} 12-\mathrm{H} 12$ & 120.8 \\
\hline $\mathrm{O} 2^{\mathrm{i}}-\mathrm{Cu} 1-\mathrm{Cu} 1^{\mathrm{i}}$ & $85.48(5)$ & $\mathrm{C} 13-\mathrm{C} 12-\mathrm{H} 12$ & 120.8 \\
\hline $\mathrm{O} 4-\mathrm{Cu} 1-\mathrm{Cu} 1^{\mathrm{i}}$ & $82.68(5)$ & $\mathrm{C} 14-\mathrm{C} 13-\mathrm{C} 12$ & $122.4(3)$ \\
\hline $\mathrm{O} 5-\mathrm{Cu} 1-\mathrm{Cu} 1^{\mathrm{i}}$ & $175.46(6)$ & $\mathrm{C} 14-\mathrm{C} 13-\mathrm{N} 3$ & $118.0(3)$ \\
\hline $\mathrm{C} 8-\mathrm{O} 1-\mathrm{Cu} 1$ & $125.04(17)$ & $\mathrm{C} 12-\mathrm{C} 13-\mathrm{N} 3$ & $119.5(3)$ \\
\hline $\mathrm{C} 8-\mathrm{O} 2-\mathrm{Cu} 1^{\mathrm{i}}$ & $120.92(16)$ & $\mathrm{C} 13-\mathrm{C} 14-\mathrm{C} 9$ & $118.9(3)$ \\
\hline $\mathrm{C} 1-\mathrm{O} 3-\mathrm{Cu} 1$ & $121.59(15)$ & $\mathrm{C} 13-\mathrm{C} 14-\mathrm{H} 14$ & 120.6 \\
\hline $\mathrm{C} 1-\mathrm{O} 4-\mathrm{Cu} 1^{\mathrm{i}}$ & $123.95(16)$ & $\mathrm{C} 9-\mathrm{C} 14-\mathrm{H} 14$ & 120.6 \\
\hline $\mathrm{C} 15-\mathrm{O} 5-\mathrm{Cu} 1$ & $121.53(18)$ & $\mathrm{O} 5-\mathrm{C} 15-\mathrm{N} 1$ & $125.2(3)$ \\
\hline $\mathrm{C} 15-\mathrm{N} 1-\mathrm{C} 16$ & $120.8(3)$ & $\mathrm{O} 5-\mathrm{C} 15-\mathrm{H} 15$ & 117.4 \\
\hline $\mathrm{C} 15-\mathrm{N} 1-\mathrm{C} 17$ & $120.4(3)$ & $\mathrm{N} 1-\mathrm{C} 15-\mathrm{H} 15$ & 117.4 \\
\hline $\mathrm{C} 16-\mathrm{N} 1-\mathrm{C} 17$ & $118.5(3)$ & $\mathrm{N} 1-\mathrm{C} 16-\mathrm{H} 16 \mathrm{~A}$ & 109.5 \\
\hline $\mathrm{O} 6-\mathrm{N} 2-\mathrm{O} 7$ & $123.3(3)$ & $\mathrm{N} 1-\mathrm{C} 16-\mathrm{H} 16 \mathrm{~B}$ & 109.5 \\
\hline $\mathrm{O} 6-\mathrm{N} 2-\mathrm{C} 6$ & $118.7(2)$ & $\mathrm{H} 16 \mathrm{~A}-\mathrm{C} 16-\mathrm{H} 16 \mathrm{~B}$ & 109.5 \\
\hline $\mathrm{O} 7-\mathrm{N} 2-\mathrm{C} 6$ & $118.0(3)$ & $\mathrm{N} 1-\mathrm{C} 16-\mathrm{H} 16 \mathrm{C}$ & 109.5 \\
\hline $\mathrm{O} 9-\mathrm{N} 3-\mathrm{O} 8$ & $124.1(3)$ & $\mathrm{H} 16 \mathrm{~A}-\mathrm{C} 16-\mathrm{H} 16 \mathrm{C}$ & 109.5 \\
\hline $\mathrm{O} 9-\mathrm{N} 3-\mathrm{C} 13$ & $117.9(3)$ & $\mathrm{H} 16 \mathrm{~B}-\mathrm{C} 16-\mathrm{H} 16 \mathrm{C}$ & 109.5 \\
\hline $\mathrm{O} 8-\mathrm{N} 3-\mathrm{C} 13$ & $118.1(3)$ & $\mathrm{N} 1-\mathrm{C} 17-\mathrm{H} 17 \mathrm{~A}$ & 109.5 \\
\hline $\mathrm{O} 3-\mathrm{C} 1-\mathrm{O} 4$ & $126.4(2)$ & $\mathrm{N} 1-\mathrm{C} 17-\mathrm{H} 17 \mathrm{~B}$ & 109.5 \\
\hline $\mathrm{O} 3-\mathrm{C} 1-\mathrm{C} 2$ & $117.4(2)$ & $\mathrm{H} 17 \mathrm{~A}-\mathrm{C} 17-\mathrm{H} 17 \mathrm{~B}$ & 109.5 \\
\hline $\mathrm{O} 4-\mathrm{C} 1-\mathrm{C} 2$ & $116.2(2)$ & $\mathrm{N} 1-\mathrm{C} 17-\mathrm{H} 17 \mathrm{C}$ & 109.5 \\
\hline $\mathrm{C} 3-\mathrm{C} 2-\mathrm{C} 7$ & $119.8(2)$ & $\mathrm{H} 17 \mathrm{~A}-\mathrm{C} 17-\mathrm{H} 17 \mathrm{C}$ & 109.5 \\
\hline $\mathrm{C} 3-\mathrm{C} 2-\mathrm{C} 1$ & $120.2(2)$ & $\mathrm{H} 17 \mathrm{~B}-\mathrm{C} 17-\mathrm{H} 17 \mathrm{C}$ & 109.5 \\
\hline $\mathrm{C} 7-\mathrm{C} 2-\mathrm{C} 1$ & $119.9(2)$ & $\mathrm{C} 18-\mathrm{N} 4-\mathrm{C} 19$ & $119.9(4)$ \\
\hline $\mathrm{C} 2-\mathrm{C} 3-\mathrm{C} 4$ & $120.1(3)$ & $\mathrm{C} 18-\mathrm{N} 4-\mathrm{C} 20$ & $119.8(4)$ \\
\hline $\mathrm{C} 2-\mathrm{C} 3-\mathrm{H} 3$ & 120.0 & $\mathrm{C} 19-\mathrm{N} 4-\mathrm{C} 20$ & $120.3(4)$ \\
\hline $\mathrm{C} 4-\mathrm{C} 3-\mathrm{H} 3$ & 120.0 & $\mathrm{O} 10-\mathrm{C} 18-\mathrm{N} 4$ & $125.5(5)$ \\
\hline $\mathrm{C} 5-\mathrm{C} 4-\mathrm{C} 3$ & $120.8(3)$ & $\mathrm{O} 10-\mathrm{C} 18-\mathrm{H} 18$ & 117.3 \\
\hline $\mathrm{C} 5-\mathrm{C} 4-\mathrm{H} 4$ & 119.6 & $\mathrm{~N} 4-\mathrm{C} 18-\mathrm{H} 18$ & 117.3 \\
\hline $\mathrm{C} 3-\mathrm{C} 4-\mathrm{H} 4$ & 119.6 & $\mathrm{~N} 4-\mathrm{C} 19-\mathrm{H} 19 \mathrm{~A}$ & 109.5 \\
\hline $\mathrm{C} 4-\mathrm{C} 5-\mathrm{C} 6$ & $118.2(2)$ & N4-C19-H19B & 109.5 \\
\hline $\mathrm{C} 4-\mathrm{C} 5-\mathrm{H} 5$ & 120.9 & $\mathrm{H} 19 \mathrm{~A}-\mathrm{C} 19-\mathrm{H} 19 \mathrm{~B}$ & 109.5 \\
\hline $\mathrm{C} 6-\mathrm{C} 5-\mathrm{H} 5$ & 120.9 & $\mathrm{~N} 4-\mathrm{C} 19-\mathrm{H} 19 \mathrm{C}$ & 109.5 \\
\hline $\mathrm{C} 5-\mathrm{C} 6-\mathrm{C} 7$ & $122.5(3)$ & $\mathrm{H} 19 \mathrm{~A}-\mathrm{C} 19-\mathrm{H} 19 \mathrm{C}$ & 109.5 \\
\hline $\mathrm{C} 5-\mathrm{C} 6-\mathrm{N} 2$ & $119.0(2)$ & $\mathrm{H} 19 \mathrm{~B}-\mathrm{C} 19-\mathrm{H} 19 \mathrm{C}$ & 109.5 \\
\hline $\mathrm{C} 7-\mathrm{C} 6-\mathrm{N} 2$ & $118.5(2)$ & $\mathrm{N} 4-\mathrm{C} 20-\mathrm{H} 20 \mathrm{~A}$ & 109.5 \\
\hline $\mathrm{C} 2-\mathrm{C} 7-\mathrm{C} 6$ & $118.6(2)$ & $\mathrm{N} 4-\mathrm{C} 20-\mathrm{H} 20 \mathrm{~B}$ & 109.5 \\
\hline $\mathrm{C} 2-\mathrm{C} 7-\mathrm{H} 7$ & 120.7 & $\mathrm{H} 20 \mathrm{~A}-\mathrm{C} 20-\mathrm{H} 20 \mathrm{~B}$ & 109.5 \\
\hline
\end{tabular}




$\begin{array}{ll}\mathrm{C} 6-\mathrm{C} 7-\mathrm{H} 7 & 120.7 \\ \mathrm{O} 2-\mathrm{C} 8-\mathrm{O} 1 & 126.1(2) \\ \mathrm{O} 2-\mathrm{C} 8-\mathrm{C} 9 & 118.0(2) \\ \mathrm{Cu} 1-\mathrm{O} 3-\mathrm{C} 1-\mathrm{O} 4 & 3.6(4) \\ \mathrm{Cu} 1-\mathrm{O} 3-\mathrm{C} 1-\mathrm{C} 2 & -174.57(15) \\ \mathrm{Cu} 1-\mathrm{O} 4-\mathrm{C} 1-\mathrm{O} 3 & -5.6(4) \\ \mathrm{Cu} 1-\mathrm{O} 4-\mathrm{C} 1-\mathrm{C} 2 & 172.56(15) \\ \mathrm{O} 3-\mathrm{C} 1-\mathrm{C} 2-\mathrm{C} 3 & 23.2(4) \\ \mathrm{O} 4-\mathrm{C} 1-\mathrm{C} 2-\mathrm{C} 3 & -155.2(3) \\ \mathrm{O} 3-\mathrm{C} 1-\mathrm{C} 2-\mathrm{C} 7 & -158.5(2) \\ \mathrm{O} 4-\mathrm{C} 1-\mathrm{C} 2-\mathrm{C} 7 & 23.1(3) \\ \mathrm{C} 7-\mathrm{C} 2-\mathrm{C} 3-\mathrm{C} 4 & -1.4(4) \\ \mathrm{C} 1-\mathrm{C} 2-\mathrm{C} 3-\mathrm{C} 4 & 176.9(3) \\ \mathrm{C} 2-\mathrm{C} 3-\mathrm{C} 4-\mathrm{C} 5 & 2.0(5) \\ \mathrm{C} 3-\mathrm{C} 4-\mathrm{C} 5-\mathrm{C} 6 & -0.8(5) \\ \mathrm{C} 4-\mathrm{C} 5-\mathrm{C} 6-\mathrm{C} 7 & -1.0(4) \\ \mathrm{C} 4-\mathrm{C} 5-\mathrm{C} 6-\mathrm{N} 2 & 179.9(3) \\ \mathrm{O} 6-\mathrm{N} 2-\mathrm{C} 6-\mathrm{C} 5 & 165.9(3) \\ \mathrm{O} 7-\mathrm{N} 2-\mathrm{C} 6-\mathrm{C} 5 & -13.7(4) \\ \mathrm{O} 6-\mathrm{N} 2-\mathrm{C} 6-\mathrm{C} 7 & -13.2(4) \\ \mathrm{O} 7-\mathrm{N} 2-\mathrm{C} 6-\mathrm{C} 7 & 167.2(3) \\ \mathrm{C} 3-\mathrm{C} 2-\mathrm{C} 7-\mathrm{C} 6 & -0.4(4) \\ \mathrm{C} 1-\mathrm{C} 2-\mathrm{C} 7-\mathrm{C} 6 & -178.7(2) \\ \mathrm{C} 5-\mathrm{C} 6-\mathrm{C} 7-\mathrm{C} 2 & 1.6(4) \\ \mathrm{N} 2-\mathrm{C} 6-\mathrm{C} 7-\mathrm{C} 2 & -179.3(2) \\ \mathrm{Cu} 1-\mathrm{O} 2-\mathrm{C} 8-\mathrm{O} 1 & -0.5(3) \\ \mathrm{Cu} 1-\mathrm{O} 2-\mathrm{C} 8-\mathrm{C} 9 & -178.98(15) \\ \mathrm{Cu} 1-\mathrm{O} 1-\mathrm{C} 8-\mathrm{O} 2 & 0.5(4) \\ & \end{array}$

N4- $220-\mathrm{H} 20 \mathrm{C}$

$\mathrm{H} 20 \mathrm{~A}-\mathrm{C} 20-\mathrm{H} 20 \mathrm{C}$

$\mathrm{H} 20 \mathrm{~B}-\mathrm{C} 20-\mathrm{H} 20 \mathrm{C}$

$\mathrm{Cu} 1-\mathrm{O} 1-\mathrm{C} 8-\mathrm{C} 9$

$\mathrm{O} 2-\mathrm{C} 8-\mathrm{C} 9-\mathrm{C} 10$

$\mathrm{O} 1-\mathrm{C} 8-\mathrm{C} 9-\mathrm{C} 10$

$\mathrm{O} 2-\mathrm{C} 8-\mathrm{C} 9-\mathrm{C} 14$

$\mathrm{O} 1-\mathrm{C} 8-\mathrm{C} 9-\mathrm{C} 14$

$\mathrm{C} 14-\mathrm{C} 9-\mathrm{C} 10-\mathrm{C} 11$

$\mathrm{C} 8-\mathrm{C} 9-\mathrm{C} 10-\mathrm{C} 11$

$\mathrm{C} 9-\mathrm{C} 10-\mathrm{C} 11-\mathrm{C} 12$

$\mathrm{C} 10-\mathrm{C} 11-\mathrm{C} 12-\mathrm{C} 13$

$\mathrm{C} 11-\mathrm{C} 12-\mathrm{C} 13-\mathrm{C} 14$

$\mathrm{C} 11-\mathrm{C} 12-\mathrm{C} 13-\mathrm{N} 3$

$\mathrm{O} 9-\mathrm{N} 3-\mathrm{C} 13-\mathrm{C} 14$

$\mathrm{O} 8-\mathrm{N} 3-\mathrm{C} 13-\mathrm{C} 14$

$\mathrm{O} 9-\mathrm{N} 3-\mathrm{C} 13-\mathrm{C} 12$

$\mathrm{O} 8-\mathrm{N} 3-\mathrm{C} 13-\mathrm{C} 12$

$\mathrm{C} 12-\mathrm{C} 13-\mathrm{C} 14-\mathrm{C} 9$

N3- $13-\mathrm{C} 14-\mathrm{C} 9$

$\mathrm{C} 10-\mathrm{C} 9-\mathrm{C} 14-\mathrm{C} 13$

$\mathrm{C} 8-\mathrm{C} 9-\mathrm{C} 14-\mathrm{C} 13$

$\mathrm{Cu} 1-\mathrm{O} 5-\mathrm{C} 15-\mathrm{N} 1$

$\mathrm{C} 16-\mathrm{N} 1-\mathrm{C} 15-\mathrm{O} 5$

$\mathrm{C} 17-\mathrm{N} 1-\mathrm{C} 15-\mathrm{O} 5$

C19-N4-C18-O10

$\mathrm{C} 20-\mathrm{N} 4-\mathrm{C} 18-\mathrm{O} 10$
109.5

109.5

109.5

$179.02(15)$

$-6.0(4)$

$175.3(2)$

$173.9(2)$

$-4.8(3)$

$1.2(4)$

$-178.9(3)$

$0.4(5)$

$-1.2(5)$

$0.5(5)$

$-179.8(3)$

$-8.5(4)$

$171.4(3)$

$171.8(3)$

$-8.4(4)$

$1.1(4)$

-178.7 (2)

$-1.9(4)$

$178.2(2)$

$-177.7(2)$

$-3.6(4)$

$-176.6(3)$

$2.5(7)$

-178.0 (4)

Symmetry code: (i) $-x+1,-y+1,-z+1$.

Hydrogen-bond geometry $\left(A,{ }^{\circ}\right)$

\begin{tabular}{lllll}
\hline$D-\mathrm{H} \cdots A$ & $D-\mathrm{H}$ & $\mathrm{H} \cdots A$ & $D \cdots A$ & $D-\mathrm{H} \cdots A$ \\
\hline $\mathrm{C} 4-\mathrm{H} 4 \cdots \mathrm{O} 4^{\mathrm{ii}}$ & 0.93 & 2.47 & $3.360(4)$ & 161 \\
$\mathrm{C} 15-\mathrm{H} 15 \cdots \mathrm{O} 1$ & 0.93 & 2.50 & $3.100(4)$ & 123 \\
$\mathrm{C} 16-\mathrm{H} 16 C \cdots \mathrm{O} 5$ & 0.96 & 2.40 & $2.770(4)$ & 102 \\
$\mathrm{C} 19-\mathrm{H} 19 A \cdots \mathrm{O} 10$ & 0.96 & 2.35 & $2.753(8)$ & 104 \\
$\mathrm{C} 20-\mathrm{H} 20 C \cdots \mathrm{O} 10^{\mathrm{iii}}$ & 0.96 & 2.59 & $3.503(7)$ & 160
\end{tabular}

Symmetry codes: (ii) $-x+1, y-1 / 2,-z+3 / 2$; (iii) $-x+2, y+1 / 2,-z+3 / 2$. 